\title{
Impact of NABL on Quality Indicators of Pre-Analytical Phase of Testing in Tertiary Care Hospital
}

\author{
Neha Mishra ${ }^{1}$, Vandana Porwal ${ }^{1 *}$, Shweta Khandelwal ${ }^{1}$, Aparna Rathi ${ }^{1}$ and Rakesh Porwal ${ }^{2}$ \\ ${ }^{1}$ Department of Pathology, Jawahar Lal Nehru Medical College, Ajmer (Rajasthan), INDIA \\ ${ }^{2}$ Department of Ophthalmology, Jawahar Lal Nehru Medical College, Ajmer (Rajasthan), INDIA
}

\section{ABSTRACT}

Background: The literature is relatively sparse on the epidemiological and histopathological profile of eyelid lesions in Rajasthan. The present study aims to characterize the histopathological profile of both non-neoplastic and neoplastic eyelid lesions from a tertiary care centre in Ajmer, Rajasthan.

Methods: A total of 55 lesions with histopathology diagnosis were included. Inflammatory non neoplastic lesions were excluded (15.38\%). The lesions were categorized into three groups according to the origin: epidermal, adnexal tumors and 'others', including melanocytic, vascular lesions and others.

Result: Total 55 biopsy specimens were evaluated of which, 44 cases $(80 \%)$ were benign, 10 cases $(18.18 \%)$ were malignant and single case $(1.81 \%)$ was pre malignant. The age distribution varied from $2-81$ years with mean age of 36.75 years. Benign lesions were seen more commonly in young boys of first decade and malignant lesions were more frequent in adult females. Most common benign tumors included epidermal cyst (31.81\%) followed by hemangioma (18.18\%), squamous papilloma $(9.09 \%)$. Six cases of adnexal tumors $(9.23 \%)$ were also noted. The most frequent malignant tumor included Basal cell carcinoma (81.81\%). Only single case of sebaceous gland carcinoma was seen.

Conclusion: Eyelid lesions are diverse and vary in clinical presentation and prognosis. Early and accurate histopathological diagnosis of these lesions is essential for proper management and favorable prognosis.

Keywords: Eyelid Tumor, Pathology, Epidermal Cyst, Basal Cell Carcinoma.

\section{Introduction}

In histopathology practice, lesions of eyelid are not uncommon. The histology of eyelid is unique comprising of skin and subcutaneous tissue with appendages, sebaceous glands (Meibomian glands and glands of Zeis), aporcine glands (glands of Moll) and eccrine sweat glands, striated muscle (orbicularis oculi), tarsus and the palpebral conjunctiva. Hence the lesions of eyelid are diverse and different in behaviour. Early histopathological diagnosis of eyelid lesions, especially malignancies, is crucial as many of the advanced tumors may cause cosmetic or functional disorders of eyelid or even distant metastases. ${ }^{[1]}$

The global distribution of eyelid swellings vary remarkably and their incidence appear to be increasing. ${ }^{[2-5]}$ Most of the eyelid lesions are benign in nature; but some are malignant and are quite similar to skin cancers and $10 \%$ of them are located at eyelid level. ${ }^{[6]}$ Basal cell carcinoma is the most common malignant eyelid tumor in eastern countries, whereas in Asia, the frequency of sebaceous gland carcinoma and squamous cell carcinoma are relatively high. ${ }^{[7]}$ Most prevalent benign lesions in various studies are dermoid cysts, nevi, epidermal cysts and papillomas. ${ }^{[8,9]}$
The literature is relatively sparse on the epidemiological and histopathological profile of eyelid lesions in Rajasthan. The present study aims to characterize the histopathological profile of both non-neoplastic and neoplastic eyelid lesions from a tertiary care centre in Ajmer, Rajasthan.

\section{Materials and Methods}

The study is carried out in Department of Pathology, JLN Medical College, Ajmer and Associated group of Hospitals, both retrospective (July 2014 to June 2015) and prospective (July 2015 to June 2017) over a period of 3 years.

For the retrospective study, blocks were retrieved from the histopathological section and re-examined.

For prospective study we received biopsy specimen in 10\% buffered formalin. A properly completed surgical pathology requisition form containing the patient's identification, age, sex, essential clinical data and tissue submitted was checked.

Total 72 ocular biopsies were received during our study period. Out of these we included 65 cases after exclusion of inadequate biopsy material like only fibromuscular 
tissue, autolysed tissue and blood clot. All the cases were processed by formalin fixation, paraffin embedding and Hematoxylin and Eosin staining. Special histochemical stains were done in necessary cases. Slides of available cases were retrieved and reviewed. The lesions were classified into non-neoplastic and neoplastic types. The non-neoplastic lesions included inflammatory, infectious, cystic and other miscellaneous lesions and were excluded. Only neoplastic lesions with histopathological confirmed diagnosis were included in the study which were typed into benign and malignant tumors. The data were then subjected to descriptive statistical tabulation and analysis.

\section{Result}

Total 65 cases of eyelid lesions received over a period of 3 years (from July 2014 to June 2017) in the Department of Pathology, J.L.N. Medical College and Associated Groups of Hospital, Ajmer. 10 case of non-neoplastic lesions were excluded. Out of 55 cases of neoplastic lesions benign, premalignant and malignant tumors comprised of $80 \%$, $1.81 \%$ and $18.18 \%$ respectively. We found the wide distribution of age ranging from 2 to 81 years with a mean age of 36.75 years. Males $(52.31 \%)$ were affected slightly more than females $(47.69 \%)$ with a ratio of 1.09:1.

The most frequent tumors observed in our study were epidermal tumors (32 lesions, 47.69\%). Benign tumors involved upper eyelid more commonly than lower eyelid. Among benign epidermal tumors, epidermal cyst was the most frequent diagnosis followed by squamous papilloma and dermoid cyst. Epidermal cyst alone comprised of $66.67 \%$ of benign epidermal lesion and $43.75 \%$ of all eyelid lesion. The age group affected was between $2 y-73 y$. A preference for left upper eyelid with no gender preference was seen.

Table 1: The distribution of Epidermal tumors $(n=32)$.
Other frequent benign epidermal tumors were squamous papilloma and dermoid cyst. Squamous papillloma occurred in middle age group between 41-50 years with mean age $36.4 \pm 12$ years affecting males more frequently. Dermoid cyst was seen in 2-30 year age group with female preponderance. (Table 1)

Single case of intra epithelial neoplasia was also noted in a 55 year old female.

The only malignant epidermal tumor diagnosed was basal cell carcinoma in our study. 8 out of 9 cases of BCC $(88.89 \%)$ were on lower eyelid and were seen more frequently in females. No case of squamous cell carcinoma was observed.

Six cases of adnexal tumors $(9.23 \%)$ were also noted. The common benign tumors were originating from sebaceous glands and apocrine glands (33.33\% each). A single case of sebaceous gland carcinoma was also observed in a 60 year old female patient on left upper eyelid. (Table 2)

The tumors other than epidermal and adnexal origin comprised of $26.15 \%$. This group included vascular tumors, melanocytic tumors and other tumors such as the xanthelasma. Vascular lesions were the most common among these tumors (47.05\%) and also second most common group of eyelid tumor after epidermal cyst. Hemangioma was the most frequently encountered vascular tumor, observed commonly in younger age group with mean age being $17.54 \pm 5.7$ years. Melanocytic tumors comprised $17.64 \%$. Nevus was the most common melanocytic tumor and was also seen in younger age group. Both hemangioma and nevi were seen more commonly in females. (Table 3)

\begin{tabular}{|l|c|c|c|}
\hline Type of tumor & No. of patients & Age (min. max.) & Gender M/F \\
\hline Benign tumor & 14 & $2 y-73 y$ & $1 / 1$ \\
Epidermal cyst & 04 & $40 y-50 y$ & $3 / 1$ \\
Squamous papilloma & 03 & $2 y-30 y$ & $1 / 2$ \\
Dermoid cyst & 01 & $20 y$ & $1 \mathrm{M}$ \\
Epidermal inclusion cyst & & & \\
\hline Malignant tumor & 09 & $40 y-70 y$ & $1 / 8$ \\
BCC & 01 & $55 y$ & $1 \mathrm{~F}$ \\
IEN & & \\
\hline
\end{tabular}

Table 2: The distribution of Adnexal tumors ( $n=06)$.

\begin{tabular}{|l|c|c|c|}
\hline Type of tumor & No. of patients & Age (min. max.) & Gender M/F \\
\hline $\begin{array}{l}\text { A) Sebaceous gland tumor } \\
\text { Benign tumor }\end{array}$ & 02 & $60 \mathrm{y}$ & $2 \mathrm{M}$ \\
$\begin{array}{l}\text { Sebaceous epithelioma } \\
\text { Malignant tumor } \\
\text { Sebaceous gland carcinoma }\end{array}$ & 01 & $60 \mathrm{y}$ & $1 \mathrm{~F}$ \\
\hline
\end{tabular}




\begin{tabular}{|c|c|c|c|}
\hline Type of tumor & No. of patients & Age (min. max.) & Gender M/F \\
\hline $\begin{array}{l}\text { B) Apocrine tumor } \\
\text { Benign tumor } \\
\text { Eccrine acrospiroma }\end{array}$ & 02 & $42 y-68 y$ & $1 / 1$ \\
\hline $\begin{array}{l}\text { C) Follicular tumor } \\
\text { Benign tumor } \\
\text { Pilomatricoma }\end{array}$ & 01 & $6 y$ & $1 \mathrm{~F}$ \\
\hline
\end{tabular}

Table 3: The distribution of other tumors ( $n=17)$.

\begin{tabular}{|l|c|c|c|}
\hline Type of tumor & No. of patients & Age (min. max.) & Gender M/F \\
\hline $\begin{array}{l}\text { A) Melanocytic tumor } \\
\text { Benign tumor } \\
\text { Nevus }\end{array}$ & 03 & $15 y-31 y$ & $1 / 3$ \\
\hline $\begin{array}{l}\text { B) Vascular tumor } \\
\text { Benign tumor }\end{array}$ & 08 & $3 y-45 y$ & $3 / 5$ \\
Capillary hemngioma & & & \\
\hline C) Others & & & \\
Benign lesion & 04 & $4 y-8 y$ & $3 / 1$ \\
Molluscum contagiosum & 01 & $27 y$ & $1 \mathrm{~F}$ \\
Xanthelesma & 01 & $12 \mathrm{~F}$ & \\
Pyogenic granuloma & & & \\
\hline
\end{tabular}

Table 4: Comparison of incidence of benign and malignant lesions of eyelid tumours with other studies.

\begin{tabular}{|c|c|c|}
\hline Eyelid lesions & Benign & Malignant \\
\hline Sanjay Chauhan et al ${ }^{[22]}(2013)$ & 78.94 & 21.06 \\
\hline${\text { Obata H et al }{ }^{[16]}(2005)}^{[2]}(1996)$ & 73 & 41.10 \\
\hline Abdi U et al ${ }^{[23]}(1985)$ & 58.9 & 17.40 \\
\hline Tesluk GC et al $\left.^{[2}{ }^{2}\right)$ & 82.6 & 18.51 \\
\hline Present study & 81.48 & \\
\hline
\end{tabular}

Table 5: Comparison of various studies on Eyelid lesions from different parts of India.

\begin{tabular}{|c|c|c|c|c|}
\hline Variables & $\begin{array}{l}\text { Krishnamurthy } \mathrm{H} \text { et al } \\
\text { (2014), Karnataka }\end{array}$ & $\begin{array}{l}\text { Rathod A et al }{ }^{[5]} \\
\text { (2015), South India }\end{array}$ & $\begin{array}{l}\text { Mohan B P et al } \\
\text { (2017), Kerala, India }\end{array}$ & $\begin{array}{l}\text { Present } \\
\text { study }\end{array}$ \\
\hline No. of cases & 235 & 100 & 414 & 65 \\
\hline Age range/ mean age & $3-85 y$ & $\begin{array}{c}\text { 37.02y (benign); } \\
58.59 y \\
\text { (malignant) }\end{array}$ & $\begin{array}{l}1-90 y \\
43.4 y\end{array}$ & $\begin{array}{l}2-81 \mathrm{y} \\
36.75 \mathrm{y}\end{array}$ \\
\hline M:F ratio & $1: 1.5$ & $1: 1.08$ & $1: 1.3$ & $1: 1.16$ \\
\hline $\begin{array}{l}\text { Most common benign } \\
\text { cystic lesion }\end{array}$ & $\begin{array}{l}\text { Epidermal } \\
\text { cyst }\end{array}$ & $\begin{array}{l}\text { Epidermal } \\
\text { cyst }\end{array}$ & $\begin{array}{l}\text { Epidermal } \\
\text { cyst }\end{array}$ & $\begin{array}{l}\text { Epidermal } \\
\text { cyst }\end{array}$ \\
\hline $\begin{array}{l}\text { Most common } \\
\text { benign neoplastic tumor }\end{array}$ & Nevus & Nevus & $\begin{array}{l}\text { Intradermal } \\
\text { nevus }\end{array}$ & Hemangioma \\
\hline $\begin{array}{l}\text { Most common } \\
\text { malignant tumor }\end{array}$ & SGC & $\mathrm{BCC}$ & SCC & $\mathrm{BCC}$ \\
\hline
\end{tabular}


Table 6: Comparison of various studies on Eyelid lesions from different parts of world.

\begin{tabular}{|c|c|c|c|c|c|}
\hline Variables & $\begin{array}{c}\text { Fouzia Farhat } \\
\text { et al } \\
\text { Pakistan } \\
\text { Pak }\end{array}$ & $\begin{array}{c}\text { Yasser h. Al-Faky } \\
\text { et al }{ }^{[16]}(2012), \\
\text { Saudi Arabia }\end{array}$ & $\begin{array}{l}\text { Mary HO et al }{ }^{[9]} \\
\text { (2013), Thailand }\end{array}$ & $\begin{array}{c}\text { Nithitha-aphat } \\
\text { C et al }{ }^{[7]}(2014) \text {, } \\
\text { Hong Kong }\end{array}$ & $\begin{array}{l}\text { Present } \\
\text { study }\end{array}$ \\
\hline No. of cases & 238 & 222 & 198 & 316 & 65 \\
\hline Age range/ mean age & $2-81 y$ & $2-87 y$ & $\begin{array}{l}\text { 54y (benign); 68y } \\
\text { (malignant) }\end{array}$ & $\begin{array}{c}54.2 \mathrm{y} \text { Age range }= \\
1 \mathrm{~m} \text { to } 99 \mathrm{y}\end{array}$ & $\begin{array}{l}2-81 \mathrm{y} \\
36.75 \mathrm{y}\end{array}$ \\
\hline M:F ratio & $1.28: 1$ & $1: 1.5$ & $1: 1.6$ & $1: 1.5$ & 1:1.16 \\
\hline $\begin{array}{l}\text { Most common benign } \\
\text { cystic lesion }\end{array}$ & - & - & Epidermal cyst & Epidermal cyst & $\begin{array}{c}\text { Epidermal } \\
\text { cyst }\end{array}$ \\
\hline $\begin{array}{l}\text { Most common } \\
\text { benign neoplastic tumor }\end{array}$ & $\begin{array}{c}\text { Epidermal } \\
\text { inclusion cyst }\end{array}$ & $\begin{array}{l}\text { Sweat gland } \\
\text { hydrocystoma }\end{array}$ & $\begin{array}{l}\text { Intra dermal } \\
\text { nevus }\end{array}$ & Intra dermal nevus & Hemangioma \\
\hline $\begin{array}{l}\text { Most common } \\
\text { malignant tumor }\end{array}$ & $\mathrm{BCC}$ & - & $\mathrm{BCC}$ & $\mathrm{BCC}$ & $\mathrm{BCC}$ \\
\hline
\end{tabular}

Abbreviations:

$\mathrm{M}=$ Male

$\mathrm{F}=$ Female

$\mathrm{BCC}=$ Basal Cell Carcinoma

IEN = Intra Epithelial Neoplasia

$\mathrm{SGC}=$ Sebaceous Gland Carcinoma

$\mathrm{SCC}=$ Squamous Cell Carcinoma

GRAPH 1: AGE WISE DISTRIBUTION OF BENIGN AND MALIGNANT NEOPLASTIC LESIONS.

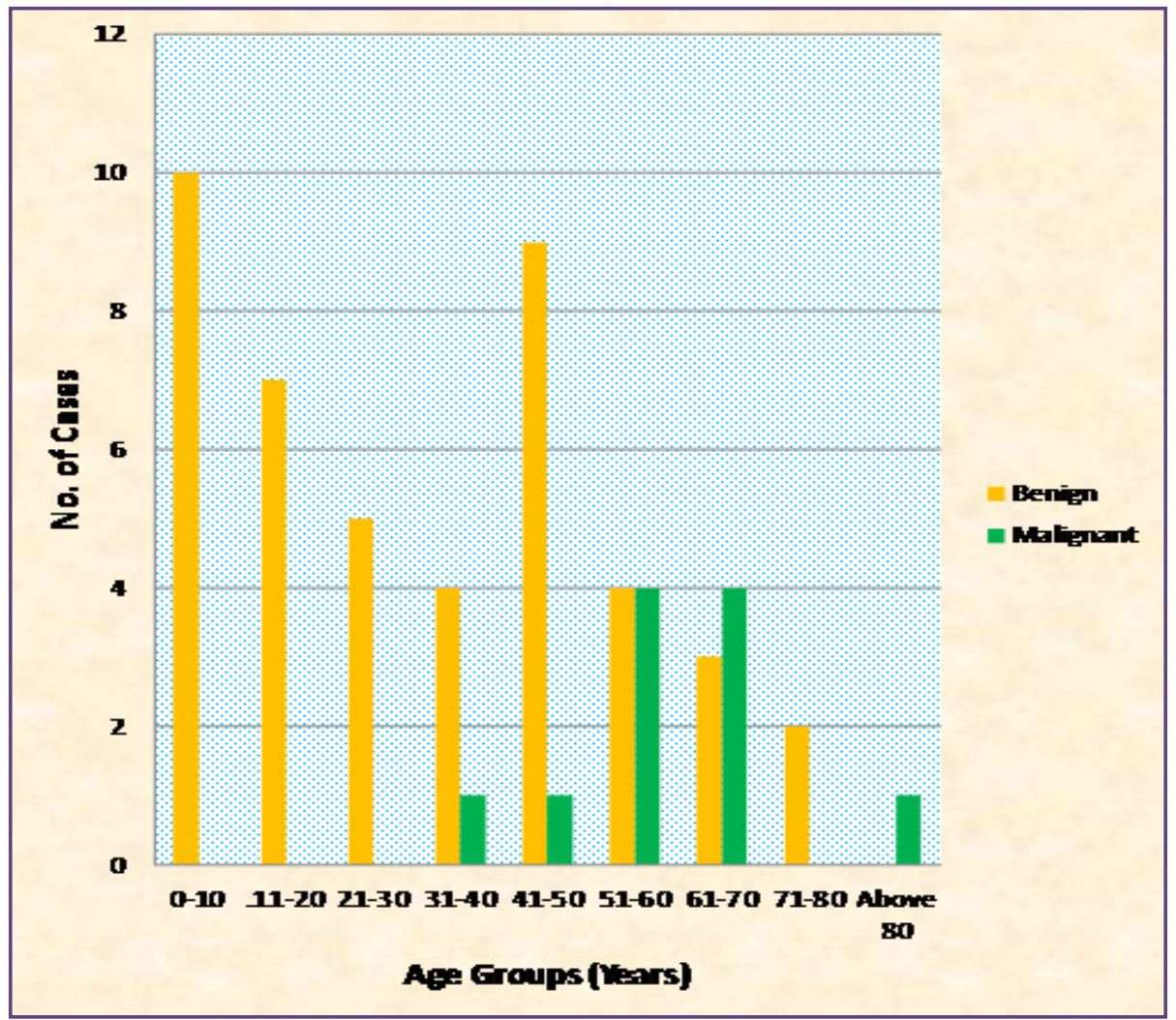

Graph 1: shows that benign lesions were seen more commonly in young boys of first decade (54.55\%) and malignant lesions were more frequent in adult females $(90 \%)$. 
GRAPH 2: COMMON BENIGN LESIONS OF EYE LID.

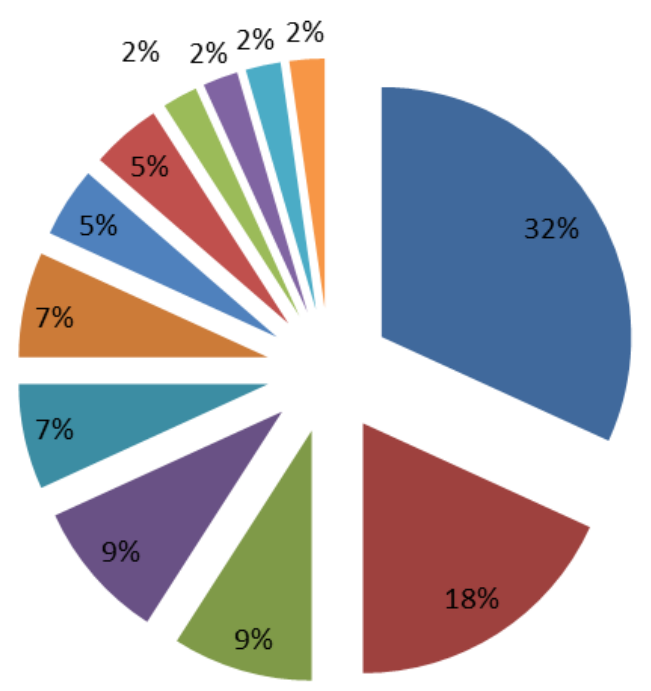

$$
\begin{aligned}
& \text { Epidermal cyst } \\
& \text { - Hemangioma } \\
& \text { - Molluscum contagiosum } \\
& \text { - Squamous papilloma } \\
& \text { - Nevus (Benign Melanoma) } \\
& \text { Dermoid cyst } \\
& \text { - Eccrine acrospiroma } \\
& \text { - Sebaceous epithelioma } \\
& \text { - Pilomatricoma } \\
& \text { - Epidermal inclusion cyst } \\
& \text { Xanthelesma }
\end{aligned}
$$

Graph 2: shows that Most common benign tumors included epidermal cyst (31.81\%) followed by hemangioma (18.18\%), squamous papilloma (9.09\%). Six cases of adnexal tumors $(9.23 \%)$ were also noted.

\section{GRAPH 3: COMMON MALIGNANT LESIONS OF EYE LID}

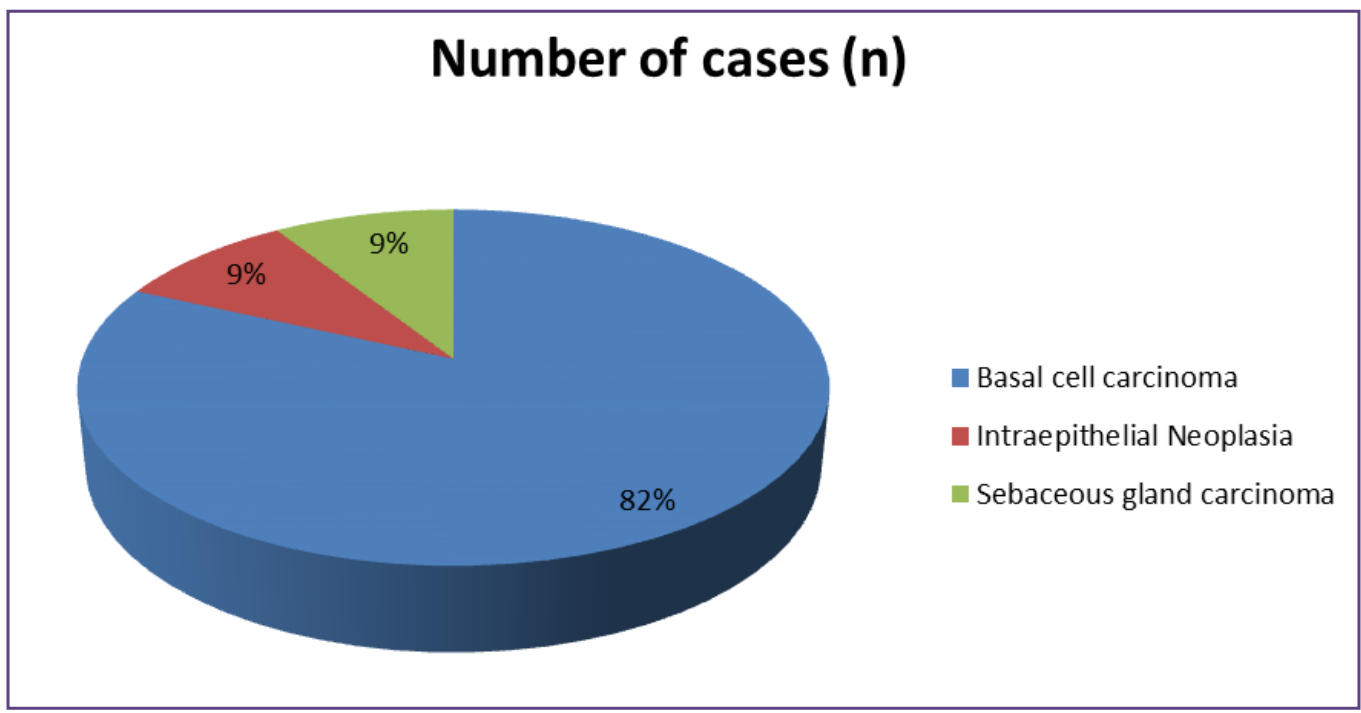

Graph 3: shows that The most frequent malignant tumor included Basal cell carcinoma (81.81\%). Only single case each of intra epithelial neoplasia and sebaceous gland carcinoma were seen.

\section{Discussion}

In clinical practice, wide variety of eyelid lesions is commonly encountered. ${ }^{[10]}$ Most of these lesions are diagnosed by their appearance and clinical behavior by clinicians. Only worrisome lesions and surgically excised tissue to check margin clarity are out for histopathological examination.

The global distribution of eyelid lesions varies remarkably due to the unique anatomical features of the eyelid as the whole skin structures, appendages, muscle, modified glands and conjunctival mucous membranes are represented in the eyelid ${ }^{[10]}$ and the incidence of such lesions has been widely reported by different previous studies. ${ }^{[2,9,11-21]}$

In our study, neoplastic lesions were more common than non-neoplastic lesions. Among neoplastic lesions, benign tumors $(81.48 \%)$ were much common than malignant ones. This is similar to study by Tesluk GC et al ${ }^{[22]}$ (1985) and 
nearly similar to study by Sanjay Chauhan et al ${ }^{[23]}$ (2013) (Table 4).

The age distribution varied from 2-81 years with mean age 36.75 years, which was comparable with different studies done in India and abroad. Female preponderance was seen in the most studies. However, in study done by Fouzia Farhat et al ${ }^{[24]}$ (2010) males outnumbered females. (Table $5 \& 6)$.

Benign lesions were seen more commonly in young boys of first decade (54.55\%) involving upper and lower eyelids with almost equal frequency. Malignant lesions were more frequent in adult females (90\%) predominantly involving the lower eyelid (90\%). This is in coherence with other studies done in India and abroad. The difference may be related to the chronic and cumulative solar damage due to increased solar exposure of the lower eyelid. ${ }^{[25]}$

The most common benign eyelid lesion was variably reported in previous literatures from different countries; Kersten ${ }^{[19]}$ (United State) and $\mathrm{Ni}{ }^{[20]}$ (China) reported Papilloma (43.9\% and 27.9\%, respectively), Chi and Beak ${ }^{\text {[21] }}$ (South Korea) found Nevus (57.1\%), while Hsu and Lin (Taiwan) ${ }^{[15]}$, Mary HO et al ${ }^{[9]}$ (Thailand) and Nathithanaphat $\mathrm{C}$ et al ${ }^{[7]}$ (Hong Kong) documented Epidermal Cyst as the most common benign eyelid lesion. In India, Rathod A et al ${ }^{[5]}$ (Hyderabad) found Nevus (17\%) while Krishnamurthy $\mathrm{H}$ et al ${ }^{[25]}$ (Karnataka) and Mohan B P et al ${ }^{[26]}$ (Kerala) found epidermal cyst as the most common benign eye lid lesions. In our study we also found epidermal cyst as the most common benign lesion (31.81\%) showing bimodal age distribution between $0-15$ years and $41-55$ years with mean age $33.45 \pm 9$ years. Males and females were equally affected. Among benign tumors hemangioma was the most common tumor $(18.18 \%)$ followed by benign appendage tumors (9.23\%). Hemangioma was affecting mostly paediatric population with mean age $17.54 \pm 5.7$ years. Benign appendage tumors mainly included sebaceous epithelioma and eccrine acrospiroma (4.54\% each) and pilomatricoma $(2.27 \%)$.

Basal cell carcinoma is the most common eyelid malignancy worldwide accounting for $80-90 \%$ of all eyelid cancer seen more commonly in western population. In Asian people it comprises 28.2-82.8\%. Light pigmentation among whites is a risk factor for $\mathrm{BCC}$; conversely, the $\mathrm{BCC}$ is rare among blacks. ${ }^{[25]}$ However in our study it was the most frequent malignant eyelid tumor (90\%) seen in older females (5565 years) with mean age of 57.56 years. This is co-incident with other studies done by J K Wang et al (Taiwan), Ni et al (US), Weiner et al (Australia), Sihota et al (India) and Abe et al (Japan). Its incidence is increasing worldwide by up to $10 \%$ a year. ${ }^{[25]}$
In Asian population (South Asian and Indians) Sebaceous cell carcinoma is more common accounting for $27-40 \%$ of all eyelid malignancies. ${ }^{[25]}$ Various studies from India by Krishnamurthy et al $(31.5 \%)$ and Mohan B P et al (2.4\%) and from other Asian countries like Thailand, Japan and China studies provide evidence, in favour of a higher proportion $(30-40 \%)$ of occurrence of SGC. ${ }^{[25]}$ But in this study, we reported only one case of Sebaceous Cell Carcinoma in 60 year old female in left upper eyelid attributed to greater number of meibomian glands in the upper lid. ${ }^{[27]}$

Metastases to the eyelids are rare, accounting for less than $1 \%$ of all malignant eyelid tumors. Melanoma and breast cancer are the most common cancers that metastasize to the eyelids (Bianciotto et al ${ }^{[28]} 2009$ ). No case of metastasis has been reported in our study.

\section{Conclusion}

Eyelid lesions are diverse and vary in clinical presentation and prognosis. Early and accurate histopathological diagnosis of these lesions is essential for proper management and favorable prognosis. In our study benign eyelid lesions affected mostly young individuals and malignant lesions occurred predominantly in elderly patients. The majority of eyelid cancers in this study were BCCs, for which a long term follow up is required. Sebaceous gland carcinoma being associated with an aggressive clinical course and poor prognosis should be treated aggressively.

\section{Acknowledgements}

Dr. Neena Kasliwal, Senior Professor, Department of Pathology

Mr. Anil Joshi Technician, Department of Pathology

Mr. Govind Ji, Technician, Department of Pathology

Mr. Ravikant Ji, Technician, Department of Pathology

\section{Reference}

1. Takamura H, Yamashita H. Clinicopathological analysis of malignant eyelid tumor cases at Yamagata University Hospital: statistical comparison of tumor incidence in Japan and in other countries. Jpn J Ophthalmol. 2005; 49:349-54.

2. Abdi UN, Tyagi V, Maheshwari V, Gogi R, Tyagi SP. Tumors of eyelid: A clinicopathologic study. J Indian Med Assoc. 1996;94:405-9.

3. Abe MY, Ohnishi Y, Hara Y, Shinoda Y, Jingu K; Malignant tumor of the eyelid-Clinical Survey during 22-year period. Jpn J Ophthalmol. 1983;27:175-84.

4. Al-Buloushi A, Filho JP, Cassie A, Arthurs B, Burnier MN. Basal cell carcinoma of the eyelid in children: A report of three cases. Eye. 2005;19:1313-4.

5. Rathod A, Pandharpukar M, Toopalli K, Bele S. A clinicopathological study of eyelid tumors and its 
management at a tertiary eye care centre of Southern India. MRIMS J Health Sci. 2015;3(1):54-8.

6. Myers M, Gurwood AS. Periocular malignancies and primary eye care. Optometry. 2001;72(11):70512.

7. Nithithanaphat C, Ausayakhun S, Wiwatwongwana D, Mahanupab P. Histopathological diagnosis of eyelid tumors in Chiang Mai University Hospital. J Med Assoc Thai. 2014;97(10):1096-9.

8. Karan S, Nathani M, Khan T, Ireni S, Khader A. Clinicopathological study of eye lid tumors in Hyderabad - A review of 57 cases. J Med Allied Sci. 2016;6(2):72-6.

9. Mary Ho, David TL Liu, Kelvin KL Chong, HK Ng, Dennis SC Lam. Eyelid tumours and pseudotumours in Hong Kong: a ten-year experience. Hong Kong Med J. 2013;19:150-5.

10. Yanoff M., Fine B.S. Ocular pathology. 5th ed. vol. 17. Mosby Inc.; 2002. (Ocular melanocytic tumors). p. 641-51 (6 (185), p. 193-4)

11. Bagheri A, Tavakoli M, Kanaani A, Zavareh R B, Esfandiari H, Aletaha M, Salour H. Eyelid Masses: A 10-year Survey from a Tertiary Eye Hospital in Tehran: Middle East African Journal of Ophthalmology Jul 9, 2013: vol 20, issue 3: page187-192.

12. Paul S, Dat T. Vo, Rona Z. Silkis et al: Malignant and Benign Eyelid Lesions in San Franscisco: Study of a Diverse Urban Population:American Journal of Clinical Medicine- Winter 2011, Volume Eight, Number One: page 40-46

13. Cook BE, Jr, Bartley GB. Epidemiologic characteristics and clinical course of patients with malignant eyelid tumors in an incidence cohort in Olmsted County, Minnesota. Ophthalmology. Apr 1999; 106 (4):746-750.

14. Deprez M, Uffer S. Clinicopathological features of eyelid skin tumors. A retrospective study of 5504 cases and review of literature. Am J Dermatopathol. 2009;31(3):256-62.

15. Hsu HC, Lin HF. Eyelid tumors in children: a clinicopathologic study of a 10-year review in southern Taiwan. Ophthalmologica

16. Yasser H. Al-Faky Epidemiology of benign eyelid lesions in patients presenting to a teaching hospital. Saudi Journal of Ophthalmology (2012) 26, 211-216.
17. Obata H, Aoki Y, Kubota S, Kanai N, Tsuru T Incidence of benign and malignant lesions of eyelid and conjunctival tumors. Nihon Ganka Gakkai Zasshi. 2005 Sep; 109 (9): 573-9.

18. Pornpanich K, Chindasub P. Eyelid tumors in Siriraj Hospital from 2000-2004. J Med Assoc Thai. 2005; 88: S11-4.

19. Kersten RC, Ewing-Chow D, Kulwin DR, Gallon M. Accuracy of clinical diagnosis of cutaneous eyelid lesions. Ophthalmology 1997; 104: 479-84.

20. Ni Z. Histopathological classification of 3510 cases with eyelid tumor. Zhonghua Yan Ke Za Zhi 1996; 32 (6): 435-7.

21. Chi MJ, Beak SH. Clinical analysis of benign eyelid and conjunctival tumors. Ophthalmologica 2006; 220: 43-51.

22. Tesluk GC, Eyelid lesions: incidence and comparison of benign and malignant lesions. Ann Ophthalmol. 1985; 17(11):704-707.

23. Sanjay C, Sejal S, Piyush S, Falguni S, Cherry S, Nailesh S. Accuracy of Clinical Diagnosis of Eyelid Lesion In A Medical College In Gujarat. Int J Res Med. 2013; 2(1);114117

24. Fouzia F, Qamar J, Mahmood S, Zia G. Evaluation of Eyelid Lesions at a Tertiary Care Hospital, Jinnah Postgraduate Medical Centre (JPMC), Karachi. Pak J Ophthalmol 2010; Vol. 26 No.2:83-86

25. Krishnamurthy $H$, Tanushree V, Venkategowda H. T, Archana S, Mobin G, et al. Profile of eyelid tumors at tertiary care institute in Karnataka: A 5 Years Survey. J Evolut Med Dent Sci. 2014;3(50):11818-32.

26. Bhavya P. Mohan, Letha V. Profile of eye lid lesions over a decade: a histopathological study from a tertiary care center in South India International Journal of Advances in Medicine. Int J Adv Med. 2017 Oct;4(5):1406-1411.

27. Dasgupta T, Wilson LD, Yu JB. A retrospective review of 1349 cases of sebaceous carcinoma. Cancer. Jan 1 2009; 115 (1): 158-165. 3117. Shastry Shrikanth. Spectrum of histopathological study of ocular lesions -1 year study. Journal of Dr. NTR University of Health Sciences. 2014;3(1):12-14.

28. Bianciotto C, Demirci H, Shields CL, et al (2009). Metastatic tumors to the eyelid: report of 20 cases and review of the literature. Arch Ophthalmol, 127, 999-1005.

*Corresponding author:

Dr. Vandana Porwal, Postal Address: 450/30, opposite old temple, Mayo link road. Ajmer (Rajasthan) - 305001 India

Phone: +91 9460355266

Email: vandana2067@gmail.com

Financial or other Competing Interests: None. 